\title{
Predator-prey interactions between the ciliate Blepharisma americanum and toxic (Microcystis spp.) and non-toxic (Chlorella vulgaris, Microcystis sp.) photosynthetic microbes
}

\author{
Ian J. Chapman ${ }^{1,2}$, Daniel J. Franklin ${ }^{1}$, Andrew D. Turner ${ }^{3}$, Eddie J. A. McCarthy ${ }^{1}$, \\ Genoveva F. Esteban ${ }^{1, *}$ \\ ${ }^{1}$ Bournemouth University, Department of Life and Environmental Sciences, Faculty of Science and Technology, Dorset, \\ BH12 5BB, UK \\ ${ }^{2}$ NSW Shellfish Program, NSW Food Authority, Taree, NSW 2430, Australia \\ ${ }^{3}$ Centre for Environment, Fisheries and Aquaculture Science (CEFAS), Weymouth, Dorset, DT4 8UB, UK
}

\begin{abstract}
Despite free-living protozoa being a major factor in modifying aquatic autotrophic biomass, ciliate-cyanobacteria interactions and their functional ecological roles have been poorly described, especially with toxic cyanobacteria. Trophic relationships have been neglected and grazing experiments give contradictory evidence when toxic taxa such as Microcystis are involved. Here, 2 toxic Microcystis strains (containing microcystins), 1 non-toxic Microcystis strain and a non-toxic green alga, Chlorella vulgaris, were used to investigate predator-prey interactions with a phagotrophic ciliate, Blepharisma americanum. Flow cytometric analysis for microalgal measurements and a rapid ultra high performance liquid chromatography-tandem mass spectrometry protocol to quantify microcystins showed that non-toxic photosynthetic microbes were significantly grazed by $B$. americanum, which sustained ciliate populations. In contrast, despite constant ingestion of toxic Microcystis, rapid egestion of cells occurred. The lack of digestion resulted in no significant control of toxic cyanobacteria densities, a complete reduction in ciliate numbers, and no observable encystment or cannibalistic behaviour (gigantism). Individual $B$. americanum morphological responses (biovolume and cell width) showed a significant decrease over time when sustained on non-toxic Microcystis compared to grazed C. vulgaris populations, supporting previous studies that cyanobacteria may be a relatively poor source of nutrition. Results here provide insight into the ecological interactions of ciliates and cyanobacteria, and for the first time $B$. americanum is shown to have the capacity to suppress potentially bloom-forming cyanobacteria. However, grazing can be significantly altered by the presence of microcystins, which could have an impact on bloom dynamics and overall community structure.
\end{abstract}

KEY WORDS: Ciliate-cyanobacteria interactions · Toxic cyanobacteria · Ciliate · Grazing • Microcystis $\cdot$ Microcystins

\section{INTRODUCTION}

Eutrophic conditions and global climate change have led to a higher occurrence of harmful algal bloom (HAB) formation, especially in temperate cyanobacteria populations (Schindler et al. 2008,

*Corresponding author: gesteban@bournemouth.ac.uk
Paerl \& Huisman 2009, Taranu et al. 2012, 2015). Certain HAB-forming genera such as Microcystis are particularly prevalent in freshwater systems like lakes and reservoirs, where densities can be found in the millions of cells ml-1 (up to $1.4 \times 10^{7}$ cells ml $^{-1}$ ) and comprise $\geq 95 \%$ of a sampled photosynthetic

(C) The authors 2019. Open Access under Creative Commons by Attribution Licence. Use, distribution and reproduction are unrestricted. Authors and original publication must be credited. 
microbial community (Moreno et al. 2004, Bozarth et al. 2010, Wu et al. 2014). Microcystis is considered a biological hazard due to its potential synthesis of potent cyanotoxins, predominately microcystins (MCs), its ability to form blooms and overall negative impacts on aquatic food webs (Chorus \& Bartram 1999, Metcalf \& Codd 2012).

Microcystis is a colony-forming cyanobacterium that has an overwintering phase in the sediment (Reynolds \& Rogers 1976, Šejnohová \& Maršálek 2012). However, not all Microcystis cells in nature exist as colonies or undergo sedimentation after summer blooms (Read et al. 2014, Chapman 2016), and recent research has revealed that it is the growth rates of non-blooming (unicellular) Microcystis in the water column during winter that significantly influence summer HAB formation (Verspagen et al. 2005, Cires et al. 2013).

The main drivers of Microcystis blooms are often attributed to abiotic factors, including temperature, light, nutrient, water flow and stratification (Šejnohová \& Maršálek 2012). Top-down pressures by grazers are often viewed as not significant due to the morphology, nutritional value and secondary metabolite production of cyanobacteria (Holm \& Shapiro 1984, von Elert et al. 2003, Wilson et al. 2006, Fink et al. 2011). Nevertheless, Microcystis are grazed by a number of organisms, including protozoa (Van Wichelen et al. 2016); although some specific interactions have been examined (Fyda et al. 2009, 2010), interactions are generally poorly known, especially when toxic cyanobacteria and ciliates are involved (Finlay \& Esteban 1998, Esteban et al. 2015), with research mainly focussing on crustacean and metazoan grazers (Ger et al. 2014, Schmid-Araya et al. 2016). Subsequently, ciliate-cyanobacteria trophic relationships stand out as a significant knowledge gap (Ger et al. 2016), where further applied ciliate-cyanobacteria research is needed to identify any species-specific interactions relating to their wider ecological function (Sigee et al. 1999, Tillmann 2004, Montagnes et al. 2008).

One ubiquitous protozoan is the model ciliate Blepharisma, a microphagous filter feeder with a global distribution in fresh, brackish and marine environments (Roberts et al. 2004, Petz et al. 2007). When environmental conditions become unfavourable and/or during nutrient limitation, Blepharisma exhibits 2 important survival strategies: namely, cannibalism and encystment (Giese 1973). This makes it an ideal candidate to test ciliate-cyanobacteria interactions, which to date have not been extensively documented.
Although ciliates play a significant role in aquatic ecosystems (Finlay \& Esteban 1998) and are frequently observed attached to Microcystis and other cyanobacterial colonies (Canter et al. 1990, Foissner et al. 1999, Van Wichelen et al. 2016), laboratory studies have documented Condylostoma vorticella and Stentor roeselii grazing on Microcystis (Takamura \& Yasuno 1983, Kim et al. 2007). The ciliate Nassula sp., has also been observed grazing on other MC-producing cyanobacteria (Canter et al. 1990, Combes et al. 2013).

Here, we studied grazing of $B$. americanum on the MC-producing cyanobacterium Microcystis along with a non-toxic Microcystis strain, and a non-cyanobacterial non-toxic alga of a similar size (Chlorella vulgaris). The Microcystis cells used were noncolony forming. We evaluated the impact of ciliate grazing by measuring prey cell reduction and intracellular MC content, as Microcystis predation has the potential to change population and cell properties, such as density and toxicity (Burkert et al. 2001, Jang et al. 2003, 2007, Yang et al. 2008), and affect community composition (Fenchel 1982, Sarnelle \& Wilson 2005, Wilson et al. 2006, Chislock et al. 2013, Ger et al. 2016). The effects of different prey types on Blepharisma were assessed at population (cell number) and individual (morphology) levels, in order to improve our understanding of cyanobacteria-ciliate interactions.

\section{MATERIALS AND METHODS}

\subsection{Culture conditions for cyanobacterium, chlorophyte and ciliate strains}

An MC-producing strain of Microcystis aeruginosa (PCC 7806) and a non-toxic mutant of the same strain (PCC 7806 -mcyB) was provided by the Pasteur Culture Collection of Cyanobacteria (Institut Pasteur of Paris, France). A fresh isolate species of toxic Microcystis (CCAP 1450/17) (Hartnell et al. 2016) and Chlorella vulgaris (CCAP 211/11B) were obtained from the Culture Collection of Algae and Protozoa (CCAP, UK).

Batch cultures were pre-cultivated in 'cap vented' Corning ${ }^{\circledR}$ cell culture flasks (Sigma-Aldrich) with a 1:1 mixture of BG-11 media (Sigma-Aldrich) and Volvic ${ }^{\circledR}$ mineral water and sterile filtered through a $0.2 \mu \mathrm{m}$ cellulose acetate filter (Minisart ${ }^{\circledR}$ plus, Sigma-Aldrich). All cultures were grown in a total of $30 \mathrm{ml}$ media and incubated under a single coolwhite fluorescent tube, providing illumination at $7 \pm$ 
$2 \mu \mathrm{E} \mathrm{m} \mathrm{m}^{-2} \mathrm{~s}^{-1}$ on a $12: 12 \mathrm{~h}$ light:dark cycle at $25 \pm 1^{\circ} \mathrm{C}$ (Conviron, CMP6010) and agitated gently by hand daily.

Non-toxic PCC 7806 cultures were also supplemented with $5 \mathrm{\mu g} \mathrm{ml}^{-1}$ of chloramphenicol (SigmaAldrich). The non-toxic PCC 7806 culture strain was generated by insertion of a chloramphenicol resistance cassette into an inactivated peptide synthesis gene required for biosynthesis of the toxic microcystin variant MC-LR (leucine and arginine) (Dittmann et al. 1997).

Blepharisma americanum was obtained from the CCAP (CCAP 1607/1, UK) and initially established with a 1:1 mixture of BG-11 media and Volvic ${ }^{\circledR}$ mineral water in Corning ${ }^{\circledR}$ cell culture flasks. Half a boiled crushed wheat grain was added to promote growth of indigenous heterotrophic bacteria. Culture flasks were placed under the same conditions as the microalgal cultures described above.

\subsection{Experimental setting}

To investigate the grazing of $B$. americanum on the various microalgal cultured strains and the prey response to predation, ciliates were introduced to individual toxic and non-toxic cultures of Microcystis and $C$. vulgaris at 2 separate cell densities each. The relative low and high starting densities of $\approx 3 \times 10^{5}$ and $\approx 1.8 \times 10^{6}$ cells $\mathrm{ml}^{-1}$ were chosen to assess the effect of $B$. americanum, as it showed a range of potential bloom or bloom-forming numbers produced in the environment by cyanobacteria, including Microcystis (Moreno et al. 2004, Paerl \& Huisman 2009, Bozarth et al. 2010, Šejnohová \& Maršálek 2012). Grazing incubations were set up in triplicate and compared to control groups. B. americanum cell number, morphology (length, width and biovolume) and cyst formation were assessed over a $32 \mathrm{~d}$ experimental period, along with Microcystis and C. vulgaris cell number, cell size (diameter), total biovolume and intracellular cyanotoxin content.

\subsection{Blepharisma americanum cultures}

To initiate the grazing experiment, $B$. americanum first needed to be isolated from its primary food source and starved. When reared on heterotrophic bacteria, B. americanum regularly achieved up to 8000 cells $\mathrm{ml}^{-1}$. Through a combination of repeated dilutions in fresh 1:1 BG-11:Volvic ${ }^{\circledR}$ mineral water and micro-pipetting, ciliate densities were reduced to 1000 cells ml${ }^{-1}$, and ciliates were then starved for
$48 \mathrm{~h}$. Before being combined with the prey, samples were checked with light microscopy to confirm the absence of heterotrophic bacteria in the media and ciliate food vacuoles.

As B. americanum are known to be cannibalistic (Giese 1973), 2 control groups were set up in triplicate to observe if that feeding habit existed under the experimental conditions selected for this study. One $30 \mathrm{ml}$ culture condition (triplicate) contained 100 cells ml ${ }^{-1}$ of $B$. americanum with no additional food source. The second control contained the same media volume and cell densities supplemented with $5 \mu \mathrm{g} \mathrm{ml}^{-1}$ of chloramphenicol. Chloramphenicol was added as its mode of action is to inhibit protein synthesis and it has the ability to affect ciliate motility (Wu et al. 1996).

\subsection{Microalgal cultures}

Stock cultures for controls from both organisms at a high biomass (high-exponential phase $\approx 8 \times 10^{6}$ cells $\mathrm{ml}^{-1}$ ) were diluted to $1 \times 10^{5}$ cells ml ${ }^{-1}$ in triplicate (30 ml total). When cultures reached cell counts of $\approx 3 \times 10^{5}$ (low) or $1.8 \times 10^{6}$ (high) cells $\mathrm{ml}^{-1}$, sizes (diameters) and intracellular toxin levels were measured. The cell densities were grown from relatively low numbers (lag phase) and chosen to experiment on as parameters like growth rates, morphology and toxin content per cell can change during different phases of a batch cycle (Long et al. 2001, Li et al. 2013).

All test groups (exposed to $B$. americanum) were set up in the same way as the control groups but to a sample volume of $27 \mathrm{ml}$, allowing for $3 \mathrm{ml}$ of $B$. americanum (1000 cells ml $\left.{ }^{-1}\right)$ for a final sample volume of $30 \mathrm{ml}$ with 100 ciliates $\mathrm{ml}^{-1}$. All control and test groups were kept under the same conditions as the stock cultures and gently agitated daily.

\subsection{Microalgal enumeration and sizing}

Total Microcystis and C. vulgaris cell counts were measured approximately every $3 \mathrm{~d}$ by flow cytometry using an Accuri C6 (BD Biosciences). Detection and discrimination of Microcystis was carried out using an argon ion $488 \mathrm{~nm}$ solid state laser $(20 \mathrm{~mW})$ and a forward angle light scatter detector (FSC-W, $90 \pm$ $\left.13^{\circ}\right)$, which recorded cell size, and a $640 \mathrm{~nm}$ red diode laser $(1.7 \mathrm{~mW})$ with a far-red channel detector (FL4-H, $675 \pm 12.5 \mathrm{~nm}$, band-pass filter) which recorded fluorescence emission from the photosynthetic accessory pigment phycocyanin. C. vulgaris measure- 
ments were carried out using the same $488 \mathrm{~nm}$ laser for both forward scatter detection (FSC-W) and separately for intracellular chlorophyll signals through a near-red detector (FL3-H, >670 nm, long pass filter).

Cell diameters were calculated through a 6-point calibration curve from flow cytometry grade polystyrene sizing beads ranging from 2.0-14.5 $\mu \mathrm{m}$ (Spherotech), with biovolume determination based on the volume of a sphere, $V=4 / 3 \pi r^{3}$, where $r=$ radius.

\subsection{Enumeration and sizing of $B$. americanum}

Ciliate samples $(0.5 \mathrm{ml})$ were fixed with Lugol's iodine (final concentration $0.0175 \% \mathrm{v} / \mathrm{v}$ ) to $1 \mathrm{ml}$. Ciliate cell and cyst numbers were determined through light microscopy (BX51 microscope, Olympus) at 40× magnification in a Sedgewick-Rafter chamber at the same time as photosynthetic microbe counts.

Ciliate cell sizes (length and width) were measured using the same samples at 100× magnification and a semi-automatic image analysis system (Camera DP70, Software package Cell ${ }^{\wedge} \mathrm{F}$, both Olympus), with biovolumes assumed to be a rotational ellipsoid (Olenina et al. 2006), $\mathrm{V}=\pi / 6 \times \mathrm{d}^{2} \times \mathrm{h}(\mathrm{d}=$ diameter, $\mathrm{h}=$ height), with a minimum of 10 ciliates measured.

\subsection{Toxin analysis}

Samples were filtered through a Whatman ${ }^{\circledR} \mathrm{GF} /$ $\mathrm{C}$ glass microfibre disc at a volume of $1 \mathrm{ml}$ approximately every $6 \mathrm{~d}$. These were immediately stored at $-80^{\circ} \mathrm{C}$ and freeze-thawed 3 times prior to extraction (room temperature). Filter discs were placed in a glass beaker containing $10 \mathrm{ml}$ of $80 \%$ methanol and allowed to extract for $24 \mathrm{~h}$ at $4 \pm 1^{\circ} \mathrm{C}$ before ultra high performance liquid chromatographytandem mass spectrometry (UHPLC-MS/MS) analysis (Turner et al. 2018). In brief, a Waters Acquity UHPLC system coupled to a Xevo TQ tandem quadrupole mass spectrometer (MS/MS) was used with a $1.7 \mu \mathrm{m}, 2.1 \times 50 \mathrm{~mm}$ Waters Acquity UHPLC $\mathrm{BEH}$ (bridged ethyl hybrid) C18 column, held at $+60^{\circ} \mathrm{C}$. Mobile phases were A1 (water $+0.025 \%$ formic acid) and B1 (acetonitrile $+0.025 \%$ formic acid). The UHPLC gradient, MS/MS source conditions and selected reaction monitoring transitions were as previously specified (Turner et al. 2018). Quantitation of MCs was performed against external calibration standards. Measurements of MCs were divided by cell counts to calculate the mass of toxin cell ${ }^{-1}$ in femtograms (fg).

\subsection{Statistical analysis}

To test the effects of ciliate grazing on Microcystis and $C$. vulgaris, an unpaired Student's $t$-test or its non-parametric equivalent (Mann-Whitney $U$-test) was performed between control (negative ciliates) and test (positive ciliates) cultures at both starting photosynthetic microbe densities to assess significant differences $(p<0.05)$ in cell numbers, cell size (diameter), total biovolumes and intracellular toxin (MC-LR) content over the experimental period. A linear regression was run if an intracellular toxin significantly differed over the experiment to assess changes in $\mathrm{MC}$ production in response to predation.

Changes in mean $B$. americanum cell numbers, cyst abundance and morphology (individual biovolume, lengths and widths) across all test and control cultures at both densities were analysed through a Kruskal-Wallis ANOVA on ranks. If ciliate abundance dropped to 0 before $32 \mathrm{~d}$ (due to population mortality), observations were still conducted until the end of the experiment, as B. americanum has the potential to re-emerge from an encystment phase. When a morphological parameter significantly changed over the experiment, a linear regression analysis was performed in order determine the effect of prey as a food source. All statistical analyses were carried out with SigmaPlot 13.0 (Systat Software) for windows and reported as means $\pm \mathrm{SE}$.

\section{RESULTS}

\subsection{Microalgal cell numbers}

Blepharisma americanum only had a grazing impact on non-toxic Microcystis PCC 7806 and Chlorella vulgaris cultures (Fig. 1). At low starting densities, there were significantly more cells in the controls for both test photosynthetic microbe cultures over the experimental period (both $\mathrm{p}<0.001$ ), where nontoxic PCC 7806 recorded $\approx 4.7 \times 10^{6} \pm 4.4 \times 10^{5}$ cells $\mathrm{ml}^{-1}$ more and $C$. vulgaris $\approx 5.9 \times 10^{6} \pm 1.5 \times 10^{6}$ cells $\mathrm{ml}^{-1}$ on Day 32 (Fig. 1).

For incubations with relatively high initial prey densities, only non-toxic PCC 7806 was significantly impacted by grazing $(\mathrm{p}<0.001)$, recording $\approx 1.0 \times 10^{7}$ $\pm 1.4 \times 10^{5}$ cells ml ${ }^{-1}$ more in the control. Although no significant difference was observed in C. vulgaris cell numbers over $32 \mathrm{~d}$, the mean populations did have $\approx 4.7 \times 10^{6} \pm 2.2 \times 10^{6}$ cells ml ${ }^{-1}$ more in the control compared to the test culture at the end of the 


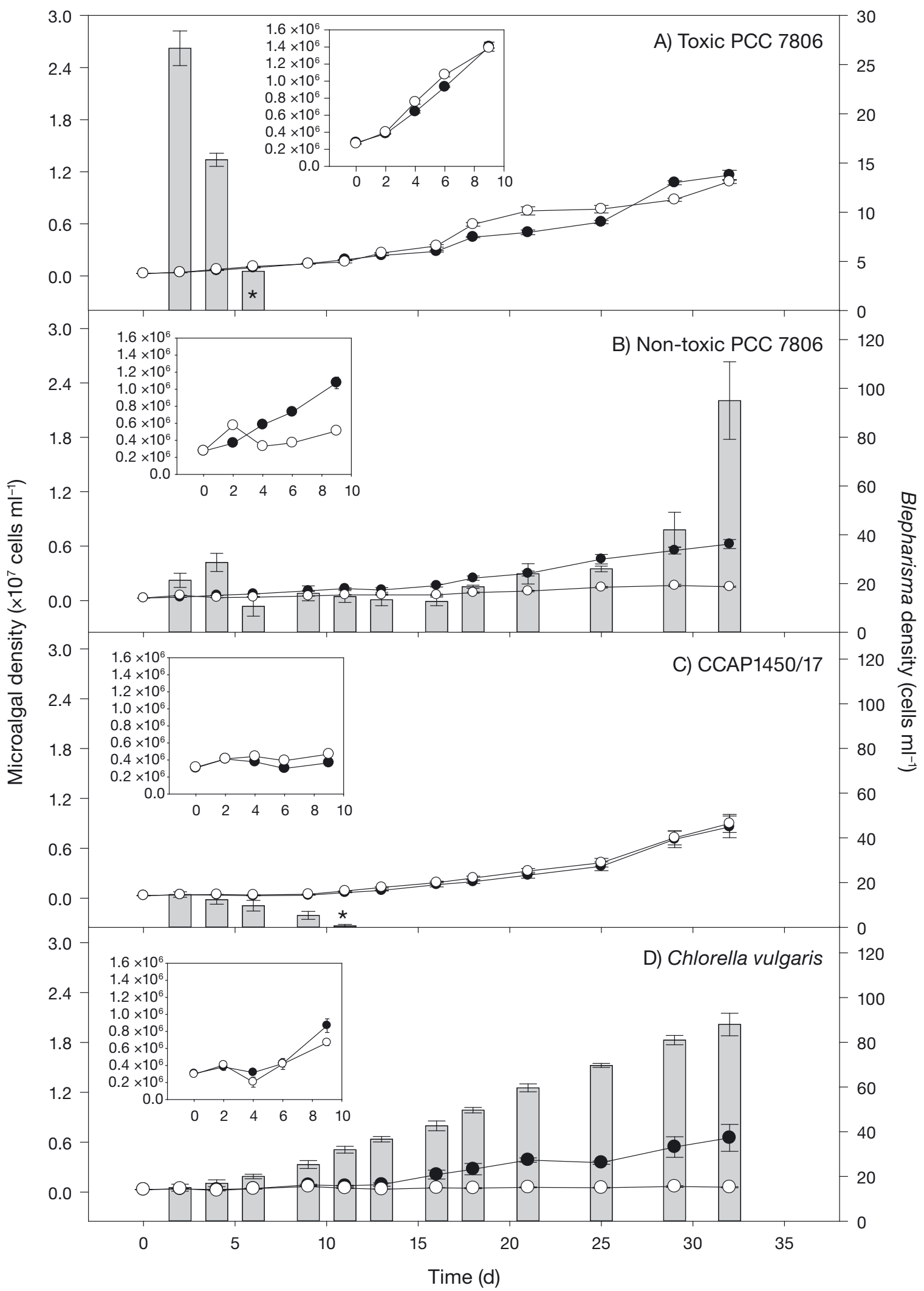

Fig. 1. Control (๑) and experimental (O) cell counts (mean and SE) for all prey cultures at low initial starting densities and test ciliate numbers (bars) over $32 \mathrm{~d}$ ( $\mathrm{n}=3$ per count). Asterisks $(*)$ correspond to the last time where Blepharisma americanum were observed. Insets show the first $10 \mathrm{~d}$ of cell counts 


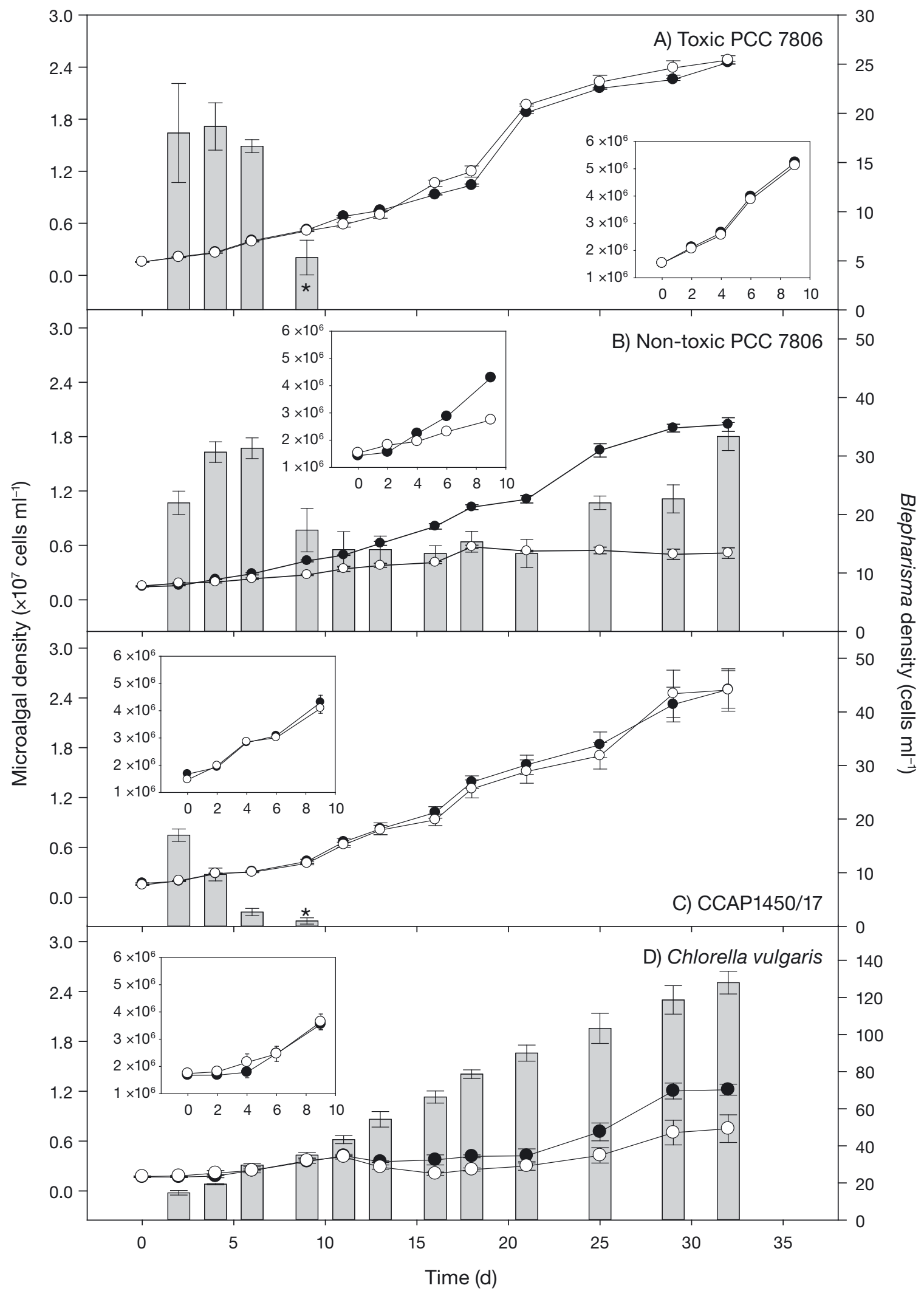

Fig. 2. Control (@) and experimental (O) cell counts (mean and SE) for all prey cultures at high initial starting densities and test ciliate numbers (bars) over $32 \mathrm{~d}(\mathrm{n}=3$ per count). Asterisks ( $*$ ) correspond to the last time where Blepharisma americanum were observed. Insets show the first $10 \mathrm{~d}$ of cell counts 


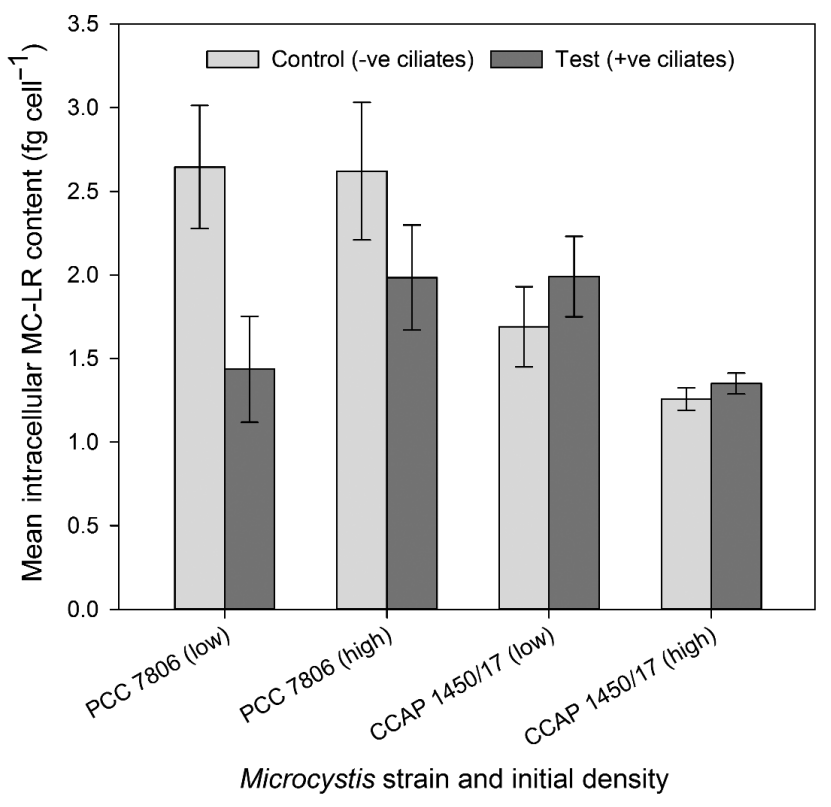

Fig. 3. Mean and SE $(n=3)$ for intracellular microcystin-LR (MC-LR) content in control and test cultures at both high and low starting densities for toxic PCC 7806 and CCAP 1450/17 Microcystis cultures

experiment (Fig. 2). However, there was a significant difference between the last 2 wk in C. vulgaris densities $(\mathrm{p}<0.05)$.

\subsection{Microalgal cell size (diameter)}

A significant cell size (diameter) difference was only recorded in $C$. vulgaris $(\mathrm{p}<0.05)$ with high starting densities, where the control $(3.51 \pm 0.07 \mu \mathrm{m})$ had a larger mean diameter over $32 \mathrm{~d}$ compared to cultures with grazing $B$. americanum $(3.43 \pm 0.08 \mu \mathrm{m})$. However, significant differences in size of $C$. vulgaris were not recorded between Days 13 and 32 (p > 0.05). Toxic PCC 7806, non-toxic PCC 7806, CCAP 1450/17 and $C$. vulgaris recorded a combined mean (control, test and both starting densities) of $4.81 \pm$ $0.03,3.70 \pm 0.04,3.59 \pm 0.05$ and $3.53 \pm 0.04 \mu \mathrm{m}$, respectively.

\subsection{Microalgal total biovolume}

At both low and high starting densities, the final total biovolume of prey was significantly different between the control and test conditions for only nontoxic PCC 7806 (low $\mathrm{p}<0.001$, high $\mathrm{p}<0.05$ ) and $C$. vulgaris (both $\mathrm{p}<0.001$ ). At low starting prey densi- ties, final total biovolumes of non-toxic PCC 7806 and C. vulgaris were $5.7 \times 10^{7} \pm 1.9 \times 10^{7} \mu^{3}$ and $7.6 \times$ $10^{7} \pm 1.6 \times 10^{7} \mu^{3}$ more in respective controls. Likewise, the controls in the high starting prey densities had a larger total biovolume, with non-toxic PCC 7806 recording $3.2 \times 10^{8} \pm 1.1 \times 10^{7} \mu^{3}$ more and $C$.

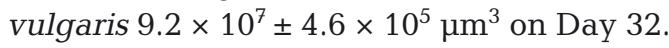

\subsection{Microalgal toxin content}

Toxic PCC 7806 and CCAP 1450/17 were the only strains that produced intracellular cyanotoxins from the standards tested (Turner et al. 2018). Toxic PCC 7806 intracellular MC (MC-LR) content significantly differed between the control and test groups at both initial prey densities (both $\mathrm{p}<0.001$ ), whereas CCAP 1450/17 did not (both $\mathrm{p}>0.05$ ).

Mean toxic PCC 7806 intracellular MC-LR was $2.62 \pm 0.15 \mathrm{fg} \mathrm{cell}^{-1}$ for the high and $2.65 \pm 0.14 \mathrm{fg}$ cell $^{-1}$ for the low density control, which was $20.6 \pm$ $0.2 \%$ and $43.2 \pm 0.2 \%$ more than both cultures containing ciliates, respectively (Fig. 3). CCAP 1450/17 recorded a combined control and test mean of $1.30 \pm$ $0.05 \mathrm{fg} \mathrm{cell}^{-1}$ for high and $1.84 \pm 0.17 \mathrm{fg} \mathrm{cell}^{-1}$ for low prey densities.

Although there was a significant difference in toxic PCC 7806 mean MC-LR intracellular content, a linear regression analysis revealed no correlation with MC-LR levels over time at both densities ( $p>0.05$ ). Representing both culture conditions and densities, toxic PCC 7806 recorded a range of $0.70-4.04 \mathrm{fg}$ cell $^{-1}$, which both increased and decreased against preceding sample points with no clear regression.

Even though both toxic PCC 7806 and CCAP $1450 / 17$ showed no significant cell number or total biovolume reduction in the presence of $B$. americanum, we observed that ingestion of toxic cells occurred (Fig. 4). Despite toxic Microcystis cells being evident in food vacuoles, these digestive organelles migrated relatively quickly to the posterior end of $B$. americanum, where cells were then expelled through the cytoproct between 5 and $10 \mathrm{~min}$ after initial ingestion (Fig. 5).

\subsection{Ciliate densities}

B. americanum cell densities significantly changed between all test cultures and the 2 controls from both initial prey densities over the experimental period ( $\mathrm{p}<0.001$ ). A post hoc analysis (Tukey's test) confirmed 2 sub-groups, with all the controls and cul- 


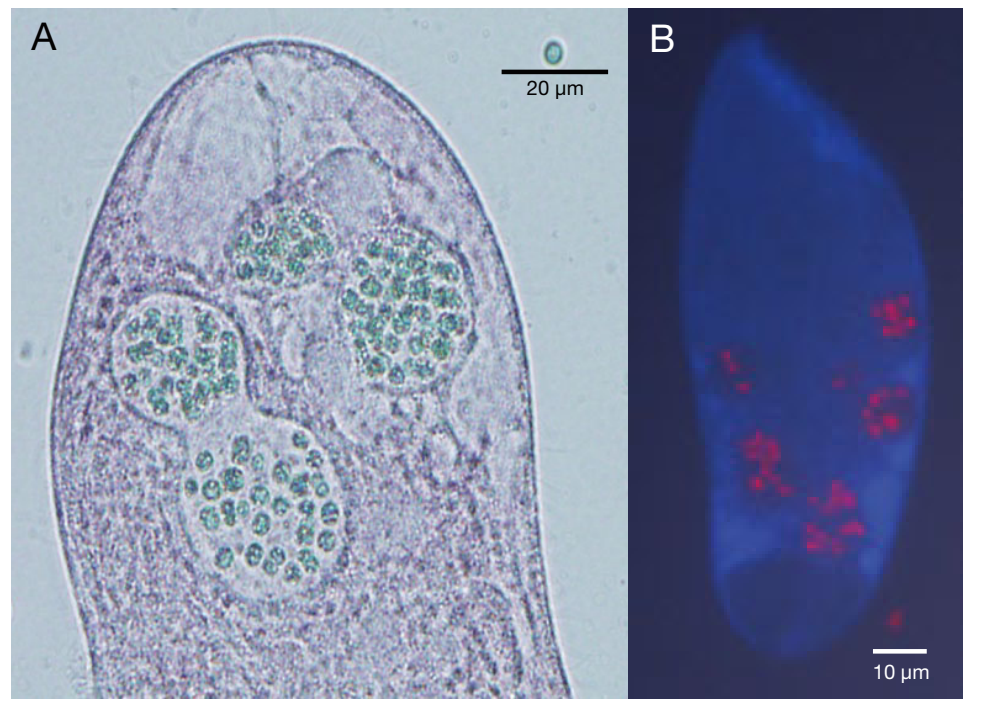

Fig. 4. (A) Light microscope image of living Blepharisma americanum with toxic PCC 7806 cells (in green) observable in its food vacuoles. (B) Epifluorescence microscopy image of $B$. americanum with ingested toxic PCC 7806 cells (in red) tures that produced MC-LR (toxic PCC7806 and CCAP 1450/17) in one and non-toxic PCC 7806 and C. vulgaris in the other.

Compared to the initial count of 100 cells ml $^{-1}$, ciliate densities in the presence of toxic cyanobacteria decreased dramatically after the first $2 \mathrm{~d}$, with no more counts recorded for both the controls and MCLR-containing cells from Days 9 and 11 in both initial microalgal densities (Figs. $1 \& 2$ ).

In contrast, $B$. americanum populations survived in all non-toxic test cultures. Consumption of non-toxic
PCC 7806 and C. vulgaris was observed throughout the experimental period where ciliate populations increased over time, albeit much slower on the diet of cyanobacteria (Figs. 1 \& 2).

Although the post hoc analysis reported that all ciliate numbers from surviving cultures were in the same sub-group, the final densities by the end of the experiment were relatively different, with non-toxic PCC 7806 recording $95 \pm 16$ (low) and $33 \pm 2$ cells $\mathrm{ml}^{-1}$ (high) and C. vulgaris with $88 \pm 5$ (low) and $128 \pm 6$ (high) cells $\mathrm{ml}^{-1}$ on Day 32 (Figs. 1 \& 2).

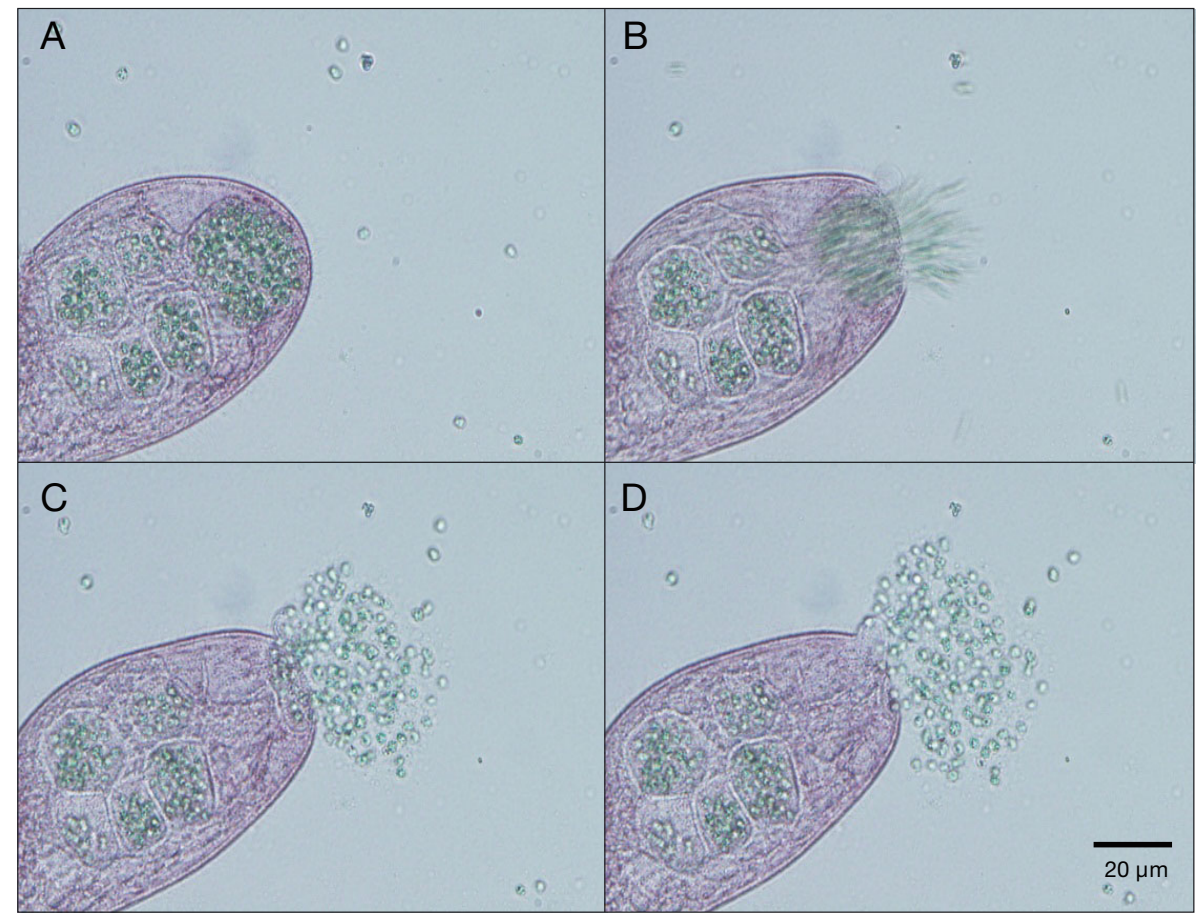

Fig. 5. (A-D) Fast frame capture of the ciliate Blepharisma americanum expelling toxic Microcystis PCC 7806 (in green) through its cytoproct into the immediate surroundings without digestion; time sequence starts at (A) and runs through to (D). Food vacuoles took approximately 5-10 $\mathrm{min}$ to release cyanotoxin (microcystinLR)-containing Microcystis cells after initial ingestion 

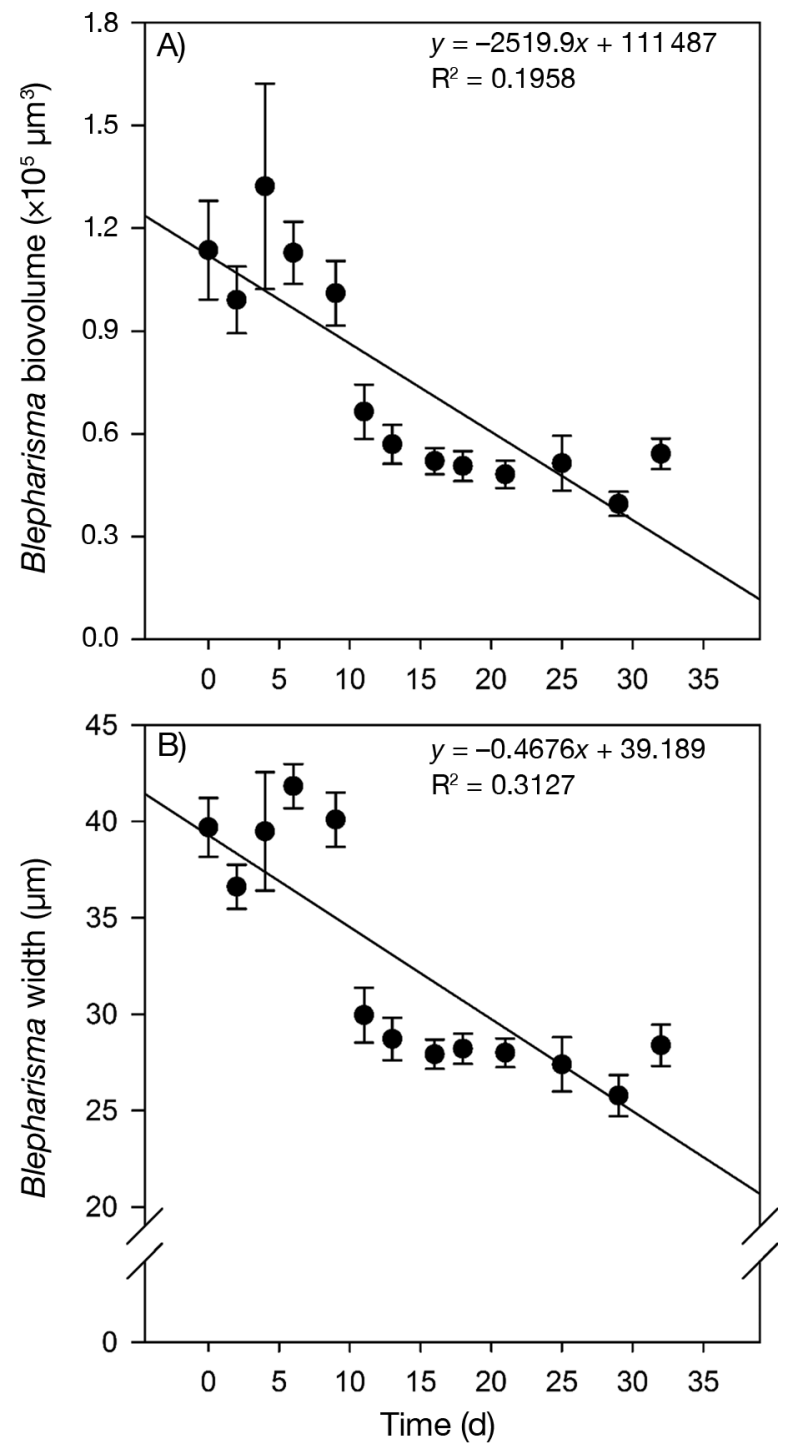

Fig. 6. Regression analysis of Blepharisma americanum (A) individual biovolumes and $(B)$ cell widths ( $\mathrm{n} \geq 10$ measurements) over the experiment when grazing on a diet of nontoxic Microcystis PCC 7806 using combined data from both low and high initial prey densities. Data are presented as means $\pm \mathrm{SE}$

\subsection{Ciliate morphology}

All ciliate morphological dimensions recorded (biovolume, length and width) showed a significant difference between the 2 test cultures (non-toxic PCC 7806 and C. vulgaris) in which $B$. americanum survived throughout the experiment (all $\mathrm{p}<0.001$ ). A post hoc analysis (Tukey's test) revealed 2 subgroups that were species specific.

Ciliate individual biovolumes that grazed on $C$. vulgaris had a mean 7 times higher than non-toxic PCC 7806. Ciliate lengths were also longer when fed on a diet of C. vulgaris over the $32 \mathrm{~d}$, recording a mean of $152.2 \pm 1.1 \mu \mathrm{m}$ compared to non-toxic PCC 7806 at $121.5 \pm 1.6 \mu \mathrm{m}$. Similarly, widths of B. americanum grazing on $C$. vulgaris showed a larger mean of $42.3 \pm 0.4 \mu \mathrm{m}$ compared to the cyanobacterium diet of $32.5 \pm 0.5 \mu \mathrm{m}$.

A linear regression analysis for ciliate morphological dimensions over time did not show any significant differences when feeding on $C$. vulgaris (all $p>0.05$ ) for both starting prey densities. Conversely, ciliates with a diet of non-toxic PCC 7806 decreased in biovolume the longer they grazed on the cyanobacterium. The combined mean biovolumes of $B$. americanum cells in both non-toxic PCC 7806 test cultures on the first day of sampling was $1.2 \times 10^{5} \pm$ $1.5 \times 10^{4} \mu^{3}$, double that of B. americanum on Day 32 (Fig. 6).

The mean lengths of $B$. americanum did not significantly change when fed with non-toxic PCC 7806 over $32 \mathrm{~d}$ for both initial starting densities (both $\mathrm{p}>0.05$ ). In contrast, mean $B$. americanum width did change significantly over time when grazing on both non-toxic PCC 7806 initial prey densities (both $\mathrm{p}<0.01)$, recording a combined mean of $39.7 \pm 1.6 \mu \mathrm{m}$ on Day 0 to $28.4 \pm 1.1 \mu \mathrm{m}$ on Day 32 (Fig. 6).

\subsection{Ciliate cysts}

Cyst number showed a significant difference between all conditions $(\mathrm{p}<0.05)$; this was due to C. vulgaris low density test cultures containing a mean of $0.2 \pm 0.1 \mathrm{cysts} \mathrm{ml}^{-1}$ compared to a combined mean of all the other cultures over the $32 \mathrm{~d}$ at $1.9 \pm 0.2$ cysts $\mathrm{ml}^{-1}$. A general decrease in cyst counts was observed for all conditions, as over half of all total cysts observed $(55 \%)$ were recorded in the first $6 \mathrm{~d}$ at $3.8 \pm$ 1.6 cysts ml ${ }^{-1}$ and $27 \%$ of the total cyst count was record over the next $7 \mathrm{~d}$ at $1.9 \pm 1.0 \mathrm{cysts} \mathrm{m}^{-1}$.

\section{DISCUSSION}

\subsection{Microalgal cell abundance and morphological responses to Blepharisma americanum grazing}

Ingestion of all Microcystis and Chlorella vulgaris strains was observed, even with cells that had intracellular MC-LR. However, those cells that contained MC-LR (toxic PCC 7806 and CCAP 1450/17) were seen to be actively expelled on a constant basis from ciliate food vacuoles into the culture media via the cytoproct (Fig. 5). Therefore, grazing of B. ameri- 
canum did not significantly decrease cell abundances and biovolume in toxic Microcystis PCC 7806 and CCAP 1450/17 cultures, providing evidence that $B$. americanum cannot digest cyanobacteria that synthesize MC-LR. In contrast, non-MC-LR-producing photosynthetic microbe cell densities (non-toxic Microcystis PCC7806 and C. vulgaris) were significantly lower when incubated with $B$. americanum compared to their controls. It must be noted that nontoxic Microcystis PCC7806 final control densities were different from the 2 toxic strains. The slower growth can be attributed to the protein inhibitor chloramphenicol, which was used to select for non-toxic cells (Dittmann et al. 1997), and that toxic strains are better adapted to carbon nutrient limitations (Jähnichen et al. 2007, Van de Waal et al. 2011). However, the negative effect on non-toxic cell numbers and ingestion of toxic cells suggest that prey items cannot be selectively handled and only discriminated when they enter the digestive system of the ciliate. Consequently, digesting only non-toxic cells would select for a toxic (MC-LR) HAB-forming species, potentially altering microbial community structure.

This study further contributes to the limited knowledge of ciliate-cyanobacteria interactions, as only Condylostoma vorticella, Stentor roeselii and a Nassula sp. have been documented to graze on Microcystis (Takamura \& Yasuno 1983, Kim et al. 2007) or an MC-LR producing cyanobacterium (Combes et al. 2013). Similar to these observations, we observed a suppression of Microcystis densities; however, more importantly, this work highlights an advance in ciliate-cyanobacterial interactions with evidence that a cyanotoxin (MC-LR) played a role in ciliate grazing and cyanobacterial mortality rates. As Takamura \& Yasuno's (1983) field observations recorded no MCLR levels, and Kim et al. (2007) used a Microcystis culture which did not produce MCs ( $M$. aeruginosa NIES-44), the presence or absence of MC-LR in this grazing experiment confirms a relationship between ciliate survival and the abundance of cyanobacteria.

Compared to other protozoa, B. americanum has relatively efficient maximum clearance rates when optimal food particle sizes are present. Fenchel (1980) calculated that maximum clearing rates of prey items as a function of cell size are optimal with cells at $6 \mu \mathrm{m}$. Here, non-toxic PCC 7806 and C. vulgaris had a combined mean diameter from both densities in test conditions of $3.78 \pm 0.06$ and $3.48 \pm$ $0.06 \mu \mathrm{m}$, respectively. As maximum clearance rates in terms of prey cell sizes needed to be increased by $61.5 \pm 2.4 \%$ for non-toxic PCC 7806 and $76.1 \pm 2.8 \%$ for $C$. vulgaris to match the optimal size of $6 \mu \mathrm{m}$
(Fenchel 1980), it could underline why both culture strains did not experience a complete population reduction and densities were only suppressed over the experiment (Figs. $1 \& 2$ ). Colony induction as a morphological response to a flagellate grazer (Ochromonas sp.) has been demonstrated in 2 strains of $M$. aeruginosa (CCAP 1450/1 (Burkert et al. 2001) and PCC 7820 (Yang et al. 2008); however, it was not observed during this grazing experiment.

The population morphology of environmental Microcystis when in mass bloom can often be described as colonial. Configuration of such HABs can mechanically interfere with filtering appendages (Lynch 1980, Lampert 1987, Wilson et al. 2006), raising questions about the suitability of the strains used, as they existed as unicellular cultures. However, ciliated protozoa such as Blepharisma and their ecological significance go beyond the mass uptake of prey items. Before an algal bloom such as Microcystis can develop, growth rates must exceed the sum of all population losses, which is significant in the water column for non-blooming overwintering Microcystis (Verspagen et al. 2005, Cires et al. 2013).

\subsection{Microalgal toxin content}

In this study, toxic PCC 7806 and CCAP 1450/17 recorded intracellular MC-LR, with toxic PCC 7806 reporting significantly lower MC-LR levels during the grazing incubation. Although the fate of cell-bound MC-LR was not determined during the experiment, it is possible that the toxic metabolite was expelled into the media, potentially pointing towards a metabolic release due to predation/ingestion or intracellular breakdown, although the exact fate of synthesized MCs still remains unclear (Rohrlack \& Hyenstrand 2007). However, we found a high degree of variability in intracellular MC-LR content over time. The variably of $\mathrm{MC}$ production could be explained by the efficiency of MC conjugate formation influenced by oxidative stress, such as light, and the specific expression levels of $\mathrm{MC}$ biosynthesis genes from individual strains (Zilliges et al. 2011, Meissner et al. 2013). Therefore, factors such as differences in light irradiance due to the culture position in the incubator, a lytic response to a virus (Paerl \& Otten 2013) or a response difference due to their culture lineage being isolated over $44 \mathrm{yr}$ apart could have affected cyanotoxin synthesis. Nonetheless, it was clear that the presence or absence of intracellular MC-LR played a significant role in the predation and control of Microcystis and $C$. vulgaris from $B$. americanum grazing. 
Genetic evidence has shown toxic cyanobacterial secondary metabolites to pre-date the evolution of potential grazers (Rantala et al. 2004). Since there are high levels of sequence divergence and the sporadic distribution of MC synthesis genes in modern cyanobacteria, it may underline why the roles of the cyanotoxins are contradictory, especially when predators are involved (Rantala et al. 2004, Babica et al. 2006). Here, the differences in intracellular MC-LR levels cannot be associated with the sporadic distribution of MC-LR synthesis genes, as seen in modern cyanobacteria (Rantala et al. 2004), as both toxic Microcystis strains recorded measurable levels of MC-LR. The expression and regulation of MC-LR may be due to the numerous ecotypes represented in strains, which adapt to survive under specific environments, acclimating to various stresses and responding to their particular surroundings, potentially extending to predation (Kaebernick et al. 2000, Pimentel \& Giani 2014).

\subsection{Ciliate population response to grazing}

B. americanum populations only survived and reproduced in experimental cultures that lacked intracellular MC-LR, with no rapid egestion of cells documented. In contrast, active expulsion of toxic cells was observed in experimental cultures that had MC-LR; however, despite being seen in the food vacuoles, acute toxicity cannot be confirmed, as active expulsion of toxic cells occurred, and the ciliate populations declined at the same rate as the nutrientstarved controls.

Therefore, the presence of MC-LR during B. americanum grazing indirectly reduces the population of this ciliate, as the absence of this toxin allows the ciliate to feed and fully digest the ingested microalgae, allowing it to maintain and even increase population densities.

The understanding of how MC-LR directly influences $B$. americanum physiology remains unclear and indeed what triggers the release and regulation of intracellular MC-LR contained within the cyanobacterium cells. It is commonly thought that MC-LR released from Microcystis is induced by the decomposition or lysis of a cell (Watanabe et al. 1992). Enzymes in the food vacuoles of $B$. americanum could initiate cell wall breakdown of both toxic Microcystis strains, causing the release of MC-LR. MC-LR within food vacuoles could then generate an expulsion response as seen in this study with minimal impact on overall toxic Microcystis populations.
If MC-LR also acts as a cell signalling info-chemical, there would be a cumulative response when enclosed in a food vacuole, as the cyanotoxin would be more concentrated compared to levels in the sample media, potentially increasing synthesis rates and/or release of the cyanotoxin.

After 3 wk on a non-toxic Microcystis diet, the ciliate populations showed a dramatic increase, but on a diet of $C$. vulgaris, ciliate numbers steadily increased from the initial drop of 100 cells $\mathrm{ml}^{-1}$ (found in all grazing incubations). With a variance of ciliate growth rates between microalgal prey types, it may indicate a different rate of adaptation to food sources by a small number $B$. americanum, which agrees with studies of grazers on freshwater photosynthetic microbes (especially Microcystis) that certain local adaptions or genotypes can be favoured (Fenchel 1982, Sarnelle \& Wilson 2005, Chislock et al. 2013). The grazing pressure towards selecting and feeding on non-MC-LR-containing algae therefore has the potential to alter aquatic ecosystems, shifting HAB toxicity dynamics.

The nutritional value of cyanobacteria for a grazer has for a long time been perceived to be very low (Holm \& Shapiro 1984, von Elert et al. 2003, Fink et al. 2011). When sustained on non-toxic Microcystis, the mean width and consequently total biovolume of individual $B$. americanum decreased over time. A similar morphological response was also observed in the ciliate control without prey, where the cell shape of $B$. americanum became elongated or spindle shaped under nutrient limitation (Giese 1973). As this study was conducted over $32 \mathrm{~d}$, a better understanding of protozoan morphological responses to grazing on MC-LR-containing cells could be seen, which may not be noted in shorter-term experiments like that of Combes et al. (2013).

Unfavourable conditions such as nutrient limitation, temperature, $\mathrm{pH}$ and oxygen levels can induce a dormant stage or gigantism (cannibalism) in many protozoa, including $B$. americanum, although under nutrient stress, no sign of cannibalism or increase in encystment took place in this study. Giese (1973) suggested that not forming giants or cysts can be part of adaptive behaviour, so if vegetative cells have not been exposed to regular temporal or seasonal stresses, they will not show rapid physiological heterogeneity. The $B$. americanum strain used during this experiment has been kept under constant stable conditions (environmental and nutrient) since 1951 (CCAP 1607/1, UK), where as a lineage it would have faced relatively little stress. As adaption to cannibalism or encystment may be lost or take a longer period 
of time (Giese 1973), it could account for the slow reproduction rates on a diet of non-toxic cyanobacteria and complete population mortality within the first week under the control settings.

An important biological driver of annual Microcystis blooms is their growth rate from overwintering water column populations (Verspagen et al. 2005, Cires et al. 2013), with seasonal changes also playing an important function structuring ciliate communities (Finlay \& Esteban 1998, Esteban et al. 2015). Therefore, the next logical steps taking the findings from this study would be to determine the relationship between Microcystis and ciliate species such as Blepharisma with mixed food sources, other biological antagonists and under temporal constraints observed in aquatic ecosystems.

Further work on ciliate grazing with Microcystis should also include polysaccharide assays, whereby either increased extracellular polysaccharide for cell aggregation or bound extracellular polysaccharide resulting in thicker cell walls would imply a morphological response, as reported by Yang et al. (2008). To consolidate the idea that extracellular release of MCLR was induced by the presence of potential predators in Microcystis populations, future work should record total MC-LR (including external/environmental levels). Additionally, grazed densities of toxic $M$. aeruginosa could be spiked with MC-LR, where significant differences in cyanotoxin levels and/or cyanobacteria densities would suggest that the cyanotoxin was an anti-grazer molecule and potentially an info-chemical. As there are strong indicators of highly strain-specific interactions with Microcystis and their biological antagonists, freshly isolated environmental strains could represent a more realistic coupled relationship (Van Wichelen et al. 2016).

\subsection{Conclusion}

The grazing of zooplankton on cyanobacteria is an essential part of aquatic microbial community dynamics, but specific ciliate-cyanobacteria trophic relationships have been severely neglected. Our study has provided insight into the ecological interactions between a specific ciliate and cyanobacteria, where $B$. americanum was observed to suppress a potentially bloom-forming cyanobacterium and for the first time documents Blepharisma actively grazing on Microcystis. During this study, it was evident that intracellular cyanotoxins (MC-LR) played a significant role in the growth rates and sustainability of microalgae and ciliates. In addition, an exclusive diet of Microcystis was also observed to lower the rate of ciliate density increase and to decrease morphological parameters compared to a diet of the common green alga $C$. vulgaris. With the ubiquitous nature of protozoa as photosynthetic microbe grazers and their ability to only digest non-toxic cells in ciliates such as Blepharisma, it may suggest that, under certain conditions, grazing pressure will favour toxic HAB development, shifting the dynamics of microbial communities. Species-specific observed feeding interactions as in this study are of ecological relevance, where indicative trophic processes give a clearer understanding of neglected relationships, such as the ones between ciliates and cyanobacteria.

Acknowledgements. We thank Bournemouth University for funding and the Centre for Environment, Fisheries and Aquaculture Science (CEFAS) for toxin analysis during this research.

\section{LITERATURE CITED}

Babica P, Bláha L, Maršálek B (2006) Exploring the natural role of microcystins - a review of effects on photoautotrophic organisms. J Phycol 42:9-20

*Bozarth CS, Schwartz AD, Shepardson JW, Colwell FS, Dreher TW (2010) Population turnover in a Microcystis bloom results in predominantly nontoxigenic variants late in the season. Appl Environ Microbiol 76:5207-5213

Burkert U, Hyenstrand P, Drakare S, Blomqvist P (2001) Effects of the mixotrophic flagellate Ochromonas sp. on colony formation in Microcystis aeruginosa. Aquat Ecol 35:9-17

Canter HM, Heaney SI, Lund JWG (1990) The ecological significance of grazing on planktonic populations of cyanobacteria by the ciliate Nassula. New Phytol 114: 247-263

Chapman IJ (2016) Developing new approaches for monitoring and controlling the toxic cyanobacterium Microcystis through flow-cytometric analysis. PhD dissertation, Bournemouth University

Chislock MF, Sarnelle O, Jernigan LM, Wilson AE (2013) Do high concentrations of microcystin prevent Daphnia control of phytoplankton? Water Res 47:1961-1970

Chorus I, Bartram J (1999) Toxic cyanobacteria in water: a guide to their public health consequences, monitoring and management. CRC Press, Boca Raton, FL

Cires S, Wörmer L, Agha R, Quesada A (2013) Overwintering populations of Anabaena, Aphanizomenon and Microcystis as potentia inocula for summer blooms. J Plankton Res 35:1254-1266

Combes A, Dellinger M, Cadel-Six S, Amand S, Comte K (2013) Ciliate Nassula sp. grazing on a microcystin-producing cyanobacterium (Planktothrix agardhii): impact on cell growth and in the microcystin fractions. Aquat Toxicol 126:435-441

* Dittmann E, Neilan BA, Erhard M, von Döhren H, Börner T (1997) Insertional mutagenesis of a peptide synthetase gene that is responsible for hepatotoxin production in the cyanobacterium Microcystis aeruginosa PCC 7806. Mol Microbiol 26:779-787 
Esteban GF, Finlay BJ, Warren A (2015) Free-living protozoa. In: Thorp JH, Rogers DC (eds) Ecology and general biology: Thorp and Covich's freshwater invertebrates, $4^{\text {th }}$ edn. Elsevier, San Diego, CA, p 113-132

Fenchel T (1980) Suspension feeding in ciliated protozoa: functional response and particle size selection. Microb Ecol 6:1-11

Fenchel T (1982) Ecology of heterotrophic microflagellates. III. Adaptations to heterogeneous environments. Mar Ecol Prog Ser 9:25-33

Fink P, Pflitsch C, Marin K (2011) Dietary essential amino acids affect the reproduction of the keystone herbivore Daphnia pulex. PLOS ONE 6:e28498

* Finlay BJ, Esteban GF (1998) Freshwater protozoa: biodiversity and ecological function. Biodivers Conserv 7: 1163-1186

Foissner W, Berger H, Schaumburg J (1999) Identification and ecology of limnetic plankton ciliates. Informationsbericht 3/99. Bayerisches Landesamt für Wasserwirtschaft, Munich

Fyda J, Nosek J, Wiackowski K, Pajdak-Stos A, Fialkowska E (2009) Effects of grazers' species identity on cyanobacteria in bitrophic and tritrophic food webs. FEMS Microbiol Ecol 68:329-339

Fyda J, Fiałkowska E, Pajdak-Stós A (2010) Dynamics of cyanobacteria-ciliate grazer activity in bitrophic and tritrophic microcosms. Aquat Microb Ecol 59:45-53

* Ger KA, Hansson LA, Lürling M (2014) Understanding cyanobacteria-zooplankton interactions in a more eutrophic world. Freshw Biol 59:1783-1798

Ger KA, Urrutia-Cordero P, Frost PC, Hansson LA, Sarnelle O, Wilson AE, Lürling M (2016) The interaction between cyanobacteria and zooplankton in a more eutrophic world. Harmful Algae 54:128-144

Giese A (1973) Blepharisma; the biology of a light-sensitive protozoan. Stanford University Press, Redwood City, CA

Hartnell DM, Chapman IJ, Esteban GF, Franklin DJ (2016) Exploiting eco-physiological niche to facilitate the separation of the freshwater cyanobacteria Microcystis sp. and Synechococcus sp. J Microbiol Methods 122:13-15

* Holm NP, Shapiro J (1984) An examination of lipid reserves and the nutritional status of Daphnia pulex fed Aphanizomenon flos-aquae. Limnol Oceanogr 29:1137-1140

*ähnichen S, Ihle T, Petzoldt T, Benndorf J (2007) Impact of inorganic carbon availability on microcystin production by Microcystis aeruginosa PCC 7806. Appl Environ Microbiol 73:6994-7002

Jang MH, Ha K, Joo GJ, Takamura N (2003) Toxin production of cyanobacteria is increased by exposure to zooplankton. Freshw Biol 48:1540-1550

Jang MH, Jung JM, Takamura N (2007) Changes in microcystin production in cyanobacteria exposed to zooplankton at different population densities and infochemical concentrations. Limnol Oceanogr 52:1454-1466

Kaebernick M, Neilan BA, Börner T, Dittmann E (2000) Light and the transcriptional response of the microcystin biosynthesis gene cluster. Appl Environ Microbiol 66: 3387-3392

Kim B, Hwang S, Kim Y, Hwang S, Takamura N, Han M (2007) Effects of biological control agents on nuisance cyanobacterial and diatom blooms in freshwater systems. Microbes Environ 22:52-58

Lampert W (1987) Laboratory studies on zooplankton cyanobacteria interactions. N Z J Mar Freshw Res 21:483-490
Ki M, Zhu W, Gao L, Lu L (2013) Changes in extracellular polysaccharide content and morphology of Microcystis aeruginosa at different specific growth rates. J Appl Phycol 25:1023-1030

K Long BM, Jones GJ, Orr PT (2001) Cellular microcystin content in N-limited Microcystis aeruginosa can be predicted from growth rate. Appl Environ Microbiol 67:278-283

Lynch M (1980) Aphanizomenon blooms: alternate control and cultivation by Daphnia pulex. In: Kerfoot WC (ed) The evolution and ecology of zooplankton communities. American Society of Limnology and Oceanography Special Symposium 3. University Press of New England, Hanover, NH, p 299-304

Meissner S, Fastner J, Dittmann E (2013) Microcystin production revisited: conjugate formation makes a major contribution. Environ Microbiol 15:1810-1820

Metcalf JS, Codd GA (2012) Cyanotoxins. In: Whitton BA (ed) Ecology of cyanobacteria II: their diversity in space and time. Springer, Dordrecht, p 651-675

Montagnes DJS, Barbosa AB, Boenigk J, Davidson K and others (2008) Selective feeding behaviour of key freeliving protists: avenues for continued study. Aquat Microb Ecol 53:83-98

* Moreno IM, Pereira P, Franca S, Cameán A (2004) Toxic cyanobacteria strains isolated from blooms in the Guadiana River (southwestern Spain). Biol Res 37:405-417

Olenina I, Hajdu S, Edler L, Wasmund N and others (2006) Biovolumes and size-classes of phytoplankton in the Baltic Sea. HELCOM Balt Sea Environ Proc 106. HELCOM, Baltic Marine Environment Protection Commission, Helsinki

*Paerl HW, Huisman J (2009) Climate change: a catalyst for global expansion of harmful cyanobacterial blooms. Environ Microbiol Rep 1:27-37

*Paerl HW, Otten TG (2013) Harmful cyanobacterial blooms: causes, consequences, and controls. Microb Ecol 65: 995-1010

* Petz W, Valbonesi A, Schiftner U, Quesada A, Cynan EllisEvans J (2007) Ciliate biogeography in Antarctic and Arctic freshwater ecosystems: endemism or global distribution of species? FEMS Microbiol Ecol 59:396-408

* Pimentel JSM, Giani A (2014) Microcystin production and regulation under nutrient stress conditions in toxic $\mathrm{Mi}$ crocystis strains. Appl Environ Microbiol 80:5836-5843

Kantala A, Fewer DP, Hisbergues M, Rouhiainen L, Vaitomaa J, Börner T, Sivonen K (2004) Phylogenetic evidence for the early evolution of microcystin synthesis. Proc Natl Acad Sci USA 101:568-573

Read DS, Bowes MJ, Newbold LK, Whiteley AS (2014) Weekly flow cytometric analysis of riverine phytoplankton to determine seasonal bloom dynamics. Environ Sci Process Impacts 16:594-603

Reynolds CS, Rogers DA (1976) Seasonal variations in the vertical distribution and buoyancy of Microcystis aeruginosa Kütz. emend. Elenkin in Rostherne Mere, England. Hydrobiologia 48:17-23

Roberts EC, Priscu JC, Laybourn-Parry J (2004) Microplankton dynamics in a perennially ice-covered Antarctic lake - Lake Hoare. Freshw Biol 49:853-869

Rohrlack T, Hyenstrand P (2007) Fate of intracellular microcystins in the cyanobacterium Microcystis aeruginosa (Chroococcales, Cyanophyceae). Phycologia 46:277-283

Sarnelle O, Wilson AE (2005) Local adaptation of Daphnia pulicaria to toxic cyanobacteria. Limnol Oceanogr 50: 1565-1570 
Schindler DW, Hecky RE, Findlay DL, Stainton MP and others (2008) Eutrophication of lakes cannot be controlled by reducing nitrogen input: results of a 37-year wholeecosystem experiment. Proc Natl Acad Sci USA 105: 11254-11258

Schmid Araya JM, Schmid PE, Tod SP, Esteban GF (2016) Trophic positioning of meiofauna revealed by stable isotopes and food web analyses. Ecology 97:3099-3109

Šejnohová L, Maršálek B (2012) Microcystis. In: Whitton BA (ed) Ecology of cyanobacteria II: their diversity in space and time. Springer Netherlands, Dordrecht, p 195-228

Sigee DC, Glenn R, Andrews MJ, Bellinger EG, Butler RD, Epton HAS, Hendry RD (1999) Biological control of cyanobacteria: principles and possibilities. Hydrobiologia 395:161-172

Takamura N, Yasuno M (1983) Food selection of the ciliated protozoa, Condylostoma vorticella in Lake Kasumigaura (Japan). Jap J Limnol 44:184-189

Taranu ZE, Zurawell RW, Pick F, Gregory-Eaves I (2012) Predicting cyanobacterial dynamics in the face of global change: the importance of scale and environmental context. Glob Change Biol 18:3477-3490

Taranu ZE, Gregory-Eaves I, Leavitt PR, Bunting L and others (2015) Acceleration of cyanobacterial dominance in north temperate-subarctic lakes during the Anthropocene. Ecol Lett 18:375-384

Tillmann U (2004) Interactions between planktonic microalgae and protozoan grazers. J Eukaryot Microbiol 51:156-168

Turner AD, Waack J, Lewis A, Edwards C, Lawton L (2018) Development and single-laboratory validation of a UHPLC-MS/MS method for quantitation of microcystins and nodularin in natural water, cyanobacteria, shellfish and algal supplement tablet powders. J Chromatogr B 1074-1075:111-123

Van de Waal DB, Verspagen JMH, Finke JF, Vournazou V and others (2011) Reversal in competitive dominance of a toxic versus non-toxic cyanobacterium in response to

Editorial responsibility: Tom Fenchel,

Helsingør, Denmark rising $\mathrm{CO}_{2}$. ISME J 5:1438-1450

*Van Wichelen J, Vanormelingen P, Codd GA, Vyverman W (2016) The common bloom-forming cyanobacterium Microcystis is prone to a wide array of microbial antagonists. Harmful Algae 55:97-111

Verspagen JMH, Snelder EOFM, Visser PM, Jöhnk KD, Ibelings BW, Mur LR, Huisman J (2005) Benthic-pelagic coupling in the population dynamics of the harmful cyanobacterium Microcystis. Freshw Biol 50:854-867

von Elert E, Martin-Creuzburg D, Le Coz JR (2003) Absence of sterols constrains carbon transfer between cyanobacteria and a freshwater herbivore (Daphnia galeata). Proc R Soc B 270:1209-1214

*Watanabe MF, Tsuji K, Watanabe Y, Harada KI, Suzuki M (1992) Release of heptapeptide toxin (microcystin) during the decomposition process of Microcystis aeruginosa. Nat Toxins 1:48-53

WWilson AE, Sarnelle O, Tillmanns AR (2006) Effects of cyanobacterial toxicity and morphology on the population growth of freshwater zooplankton: meta-analyses of laboratory experiments. Limnol Oceanogr 51:1915-1924

* Wu C, Clift P, Fry CH, Henry JA (1996) Membrane action of chloramphenicol measured by protozoan motility inhibition. Arch Toxicol 70:850-853

* Wu Y, Li L, Gan N, Zheng L and others (2014) Seasonal dynamics of water bloom-forming Microcystis morphospecies and the associated extracellular microcystin concentrations in large, shallow, eutrophic Dianchi Lake. J Environ Sci (China) 26:1921-1929

* Yang Z, Kong F, Shi X, Zhang M, Xing P, Cao H (2008) Changes in the morphology and polysaccharide content of Microcystis aeruginosa (Cyanobacteria) during flagellate grazing. J Phycol 44:716-720

* Zilliges Y, Kehr JC, Meissner S, Ishida K and others (2011) The cyanobacterial hepatotoxin microcystin binds to proteins and increases the fitness of Microcystis under oxidative stress conditions. PLOS ONE 6:e17615

Submitted: September 27, 2018; Accepted: June 8, 2019

Proofs received from author(s): September 3, 2019 